\title{
The Use of Audiovisual Media to Improve the Speech Skills of Private School Students
}

\section{Friska Hadi Septiarini}

SD Negeri Suro

Friskahadi85@gmail.com

\section{Article History}

accepted 14/11/2020

approved $21 / 11 / 2020$

published 26/11/2020

\begin{abstract}
This study aims to improve speaking skills through the use of audiovisual media in class IB SD Negeri Suro, Kalibagor District. Speaking skills observed in this study include linguistic and nonlinguistic aspects. In the linguistic aspect, it consists of stress, speech, vocabulary / diction, and sentence structure, while in the non-linguistic aspect it consists of fluency, disclosure of speech material, courage and attitude. This type of research is Classroom Action Research (CAR) which consists of 2 cycles. The subjects of this study were 22 students of SD Negeri Suro class $I B$. The research design used includes the planning, implementation, observation, and reflection stages. The data collection instruments used were performance tests, teacher and student observation sheets and documentation. The data analysis technique used is descriptive quantitative data analysis. This study shows that the use of audiovisual media can improve the speaking skills of grade IB SD Negeri Suro students in terms of process and outcome. The process improvement is seen from the average results of student activity observations which are included in the good category in the first cycle with a percentage of $45.5 \%$ increasing in the second cycle to $68 \%$ and are included in the very good category. In terms of results, it is evidenced by the average value of students' speaking skills in pre-action 67.54 increased to 73.05 in cycle I and increased to 75.64 in cycle II.
\end{abstract}

Keywords: audiovisual media, speaking skills

\begin{abstract}
Abstrak
Penelitian ini bertujuan untuk meningkatkan keterampilan berbicara melalui penggunaan media audiovisual pada siswa kelas IB SD Negeri Suro Kecamatan Kalibagor. Keterampilan berbicara yang diamati pada penelitian ini meliputi aspek kebahasaan dan nonkebahasaan. Pada aspek kebahasaan terdiri dari tekanan, ucapan, kosakata/diksi, dan struktur kalimat, sedangkan pada aspek nonkebahasaan terdiri dari kelancaran, pengungkapan materi wicara, keberanian dan sikap. Jenis penelitian ini adalah Penelitian Tindakan Kelas (PTK) yang terdiri dari 2 siklus. Subjek penelitian ini adalah siswa kelas IB SD Negeri Suro yang berjumlah 22 siswa. Desain penelitian yang digunakan meliputi tahap perencanaan, pelaksanaan, observasi, dan refleksi. Instrumen pengumpulan data yang digunakan adalah tes unjuk kerja, lembar observasi guru dan siswa serta dokumentasi. Teknik analisis data yang digunakan adalah analisis data deskriptif kuantitatif. Penelitian ini menunjukkan bahwa penggunaan media audiovisual dapat meningkatkan keterampilan berbicara siswa kelas IB SD Negeri Suro dari segi proses maupun hasil. Peningkatan proses dilihat dari rata-rata hasil observasi aktivitas siswa yang temasuk dalam kategori baik pada siklus I dengan persentasi $45,5 \%$ meningkat pada siklus II menjadi $68 \%$ dan termasuk dalam kategori sangat baik. Dilihat dari segi hasil, dibuktikan dengan nilai rata-rata keterampilan berbicara siswa pada pratindakan 67,54 meningkat menjadi 73,05 pada siklus I dan meningkat menjadi 75.90 pada siklus II.
\end{abstract}

Kata kunci: media audiovisual, keterampilan berbicara

Social, Humanities, and Education Studies (SHEs): Conference Series https://jurnal.uns.ac.id/shes

p-ISSN 2620-9284

e-ISSN 2620-9292 


\section{PENDAHULUAN}

.Pendidikan adalah usaha sadar terencana untuk mewujudkan suasana belajar dan proses pembelajaran agar siswa secara aktif dapat mengembangkan potensi dirinya untuk memiliki kekuatan spiritual keagamaan, pengendalian diri, kepribadian, kecerdasan, akhlak mulia, serta keterampilan yang diperlukan dirinya, masyarakat, bangsa, dan negaranya. Dalam sekolah keberadaan guru dan murid sangatlah vital. Apabila dalam sebuah sekolah tanpa ada guru dan murid maka proses pendidikan tidak akan dapat berlangsung atau terlaksana. Program kelas tidak akan berarti bilamana tidak diwujudkan dengan adanya kegiatan belajar mengajar. Antara guru dan murid mempunyai peran yang sangat penting.

Sekolah Dasar memiliki fungsi dan peran strategis dalam melahirkan generasigenerasi masa depan yang terampil berbahasa Indonesia secara baik dan benar. Melalui pembelajaran bahasa Indonesia, para peserta didik diajak untuk berlatih dan belajar berbahasa melalui aspek keterampilan mendengarkan, berbicara, membaca, dan menulis. Dengan memiliki keterampilan berbahasa Indonesia secara baik dan benar, kelak mereka diharapkan menjadi generasi yang cerdas, kritis, kreatif, dan berbudaya.

Berdasarkan pengamatan yang dilakukan, terdapat masalah mendasar pada SDN Suro, dimana siswa kelas I belum dapat berkomunikasi dengan baik pada situasi formal di kelas karena rendahnya kemampuan mereka dalam berbicara. Keterampilan berbicara siswa kelas IB SDN Suro berada pada tingkat yang rendah, terutama pilihan katanya, kalimatnya tidak efektif, struktur tuturannya rancu, dan tidak komunikatif.

Berdasarkan uraian di atas, maka penelitian ini difokuskan pada upaya untuk meningkatkan keterampilan berbicara siswa kelas IB SDN Suro melalui media audiovisual dengan Metode discovery learning. Hal ini berdasarkan pada hipotesa yang disebabkan oleh kurangnya inovasi dalam pembelajaran sehingga kegiatan pembelajaran keterampilan berbicara di kelas I SDN Suro tidak berkembang. Salah satu pendekatan pembelajaran yang diduga mampu mewujudkan situasi pembelajaran yang kondusif, dinamis, dan menyenangkan adalah melalui media audiovisual dengan metode discovery learning, karena dengan media audiovisual, proses pembelajaran anak akan berlangsung guna mencapai tujuan yang diharapkan.

Oleh sebab itu, guru kelas IB SDN Suro bertindak selaku peneliti tertarik melakukan penelitian tindakan kelas dengan judul "PENGGUNAAN MEDIA AUDIOVISUAL UNTUK MENINGKATKAN KETERAMPILAN BERBICARA PESERTA DIDIK SEKOLAH DASAR" untuk dijadikan strategi dalam mengatasi kendala yang dihadapi.

Kemendikbud (2013:193) pembelajaran tematik dilaksanakan dengan menggunakan prinsip pembelajaran terpadu. Pembelajaran terpadu menggunakan tema sebagai pemersatu kegiatan pembelajaran yang memadukan beberapa mata pelajaran sekaligus dalam satu kali tatap muka, untuk memberikan pengalaman yang bermakna bagi siswa. Karena siswa dalam memahami sebuah konsep yang mereka pelajari selalu melalui pengalaman langsung dan menghubungkannya dengan konsep lain yang telah dikuasainya

Kata Pembelajaran mempunyai makna sebagai hubungan atau interkasi peserta didik dengan guru. Sedangkan Tematik adalah asal kata dari tema yang berarti gagasan utama yang menjadi bahasan sebuah perbincangan. Lalu terdapat kata Terpadu yang berarti penyatuan atau pemaduan beberapa hal sehingga terciptanya satu kesatuan yang bermakna khususnya dalam hal pemaduan atau penyatuan mata pelajaran.

Dalam hal ini dapat disimpulkan bahwa pembelajaran tematik terpadu adalah pembelajaran yang menggunakan tema dengan memadukan beberapa mata pelajaran melalui penggunaan tema sehingga dapat memberikan pengalaman yang berarti kepada peserta didik. 
Menurut Sukiman (2012: 184), media audio visual adalah media penyalur pesan dengan memanfaatkan indera pendengaran dan penglihatan. Sedangkan Yudhi Munadi (2013: 56), sependapat dengan pernyataan diatas, bahwa media audio visual adalah media yang melibatkan indera pendengaran dan penglihatan sekaligus dalam satu proses.

Berdasarkan penjelasan di atas, maka media pembelajaran audio visual dapat dinyatakan sebagai alat yang secara fisik digunakan untuk menyampaikan isi materi pengajaran yang berupa perangkat keras yang memberikan penekanan pada pengalaman konkrit atau nonverbal melalui mata dan telinga dalam proses belajar. Media audio visual dapat diklasifikasikan sebagai media video. Video tersebut dapat diputar dengan bantuan perangkat keras dan perangkat lunak. Video atau gambar hidup merupakan gambar-gambar dalam frame dimana frame demi frame di proyeksikan melalui lensa proyektor secara mekanis sehingga pada layar terlihat gambar hidup.

Audio visual atau pandang dengar merujuk kepada penggunaan komponen suara (audio) dan komponen gambar (visual), dibutuhkan beberapa peralatan untuk dapat menyajikan hal ini. Film dan program televisi adalah beberapa contoh dari penyajian audio visual ini.

Keterampilan berbicara merupakan kemampuan mengucapkan bunyi- bunyi artikulasi atau kata-kata untuk mengekspresikan, menyatakan serta menyampaikan maksud (ide, pikiran, isi hati) seseorang kepada orang lain dengan bahasa lisan. Berbicara merupakan salah satu bentuk komunikasi lisan yang melibatkan beberapa hal yaitu: pihak yang berkomunikasi, informasi yang dikomunikasikan, dan alat komunikasi.

Keterampilan berbicara merupakan sesuatu yang penting. Menurut Hurlock (Tadkiroatun Musfiroh, 2005: 102), keterampilan berbicara sangat mempengaruhi penyesuaian sosial dan pribadi anak.

a. Anak yang pandai berbicara akan memperoleh pemuasan kebutuhan dan keinginan. Karena seseorang akan menyampaikan yang dibutuhkan dan diinginkan orang lain.

b. Anak yang pandai berbicara memperoleh perhatian dari orang lain. Hal ini karena pada hakikatnya anak senang menjadi pusat perhatian.

c. Anak yang pandai berbicara, mampu membina hubungan dengan orang lain dan dapat memerankan kepimimpinannya daripada anak yang tidak pandai berbicara.

d. Anak yang pandai berbicara akan memperoleh penilaian yang baik, kaitannya dengan isi dan cara berbicara. Berbicara mengisyaratkan latar belakang yang baik pula.

e. Anak yang pandai berbicara akan memiliki kepercayaan diri dan penilaian diri yang positif, terutama setelah mendengar komentar orang tentang dirinya.

f. Anak yang pandai berbicara biasanya memiliki kemampuan akademik yang lebih baik. Anak yang memiliki banyak kosa kata cenderung berhasil dalam meraih prestasi akademik.

g. Anak yang pandai berbicara lebih mampu memberikan komentar positif dan menyampaikan hal-hal yang baik kepada lawan bicara sehingga mempertinggi kesempatan anak untuk diterima orang lain.

h. Anak yang pandai berbicara cenderung pandai mempengaruhi dan meyakinkan teman sebayanya. Hal ini mendukung posisi anak sebagai pemimpin.

Maka keterampilan berbicara sangat penting dalam berkomunikasi dan berinteraksi dengan orang lain. Lebih khusus lagi keterampilan berbicara yang baik akan mendukung proses belajar mengajar

Berdasarkan identifikasi masalah di atas, rumusan masalah penelitian ini adalah: Bagaimanakah peningkatan keterampilan berbicara melalui penggunaan media audiovisual pada siswa kelas IB SDN Suro 
Tujuan penelitian ini ialah untuk meningkatkan keterampilan berbicara siswa kelas IB SDN Suro melalui penggunaan media audiovisual.

\section{METODE}

Penelitian ini adalah Penelitian Tindakan Kelas yang digunakan peneliti adalah jenis PTK kolaboratif. PTK kolaboratif yaitu kerja sama antara peneliti dengan teman sejawat sebagai observer. Penelitian Tindakan kelas ini menggunakan Langkahlangkah Model Kemmis dan Mc Taggart yang meliputi Penyusunan Perencanaan, Pelaksanaan Tindakan, Observasi (Pengamatan), Refleksi.

Penelitian ini dilaksanakan pada semester I tahun pelajaran 2020/2021. Subjek dalam penelitian ini adalah siswa kelas I B SD Negeri Suro Kecamatan Kalibagor Kabupaten Banyumas dengan jumlah siswa 22 anak.

Untuk memperoleh data yang diinginkan diperlukan teknik dan alat yang tepat agar data yang dibutuhkan dapat terkumpul. Dalam penelitian ini, peneliti menggunakan lembar observasi, tes dan dokumentasi kegiatan siswa.

Observasi merupakan suatu teknik atau cara menumpulkan data dengan jalan mengadakan pengamatan terhadap kegiatan yang sedang berlangsung. Kegiatan tersebut bisa berkenaan dengan pengamatan implementasi RPP digunakan untuk mendapat data tentang pengajaran guru didalam kelas serta pengamatan keaktifan siswa, sehingga bisa dilihat di dalam pelaksanaan pembelajaran benar-benar sesuai dengan kondisi dan proses yang diharapkan

Tes digunakan untuk mengukur keterampilan berbicara siswa dengan audiovisual. Untuk tes keterampilan berbicara, digunakan pedoman penilaian keterampilan berbicara berupa penilaian rubrik. Pada penelitian ini tes yang digunakan berupa tes unjuk kerja.

Dokumentasi merupakan suatu teknik pengumpulan data dengan menghimpun dan menganalisis dokumen-dokumen tertulis, gambar maupun elektronik. Dokumendokumen yang dihimpun dipilih sesuai dengan tujuann dan fokus masalah. Dalam penelitian ini dokumentasi yang digunakan yaitu berupa foto-foto selama proses belajar mengajar dikelas.

Teknik analis data yang peneliti gunakan dalam penelitian ini adalah analisis data deskripsi kuantitatif.

\section{HASIL DAN PEMBAHASAN}

Pelaksanaan Tindakan Siklus 1

a. Perencanaan

Perencanaan tindakan dalam siklus I dapat diuraikan beberapa langkah yaitu sebagai berikut.

1) Mengidentifikasi masalah melalui wawancara dengan guru kelas I B dan observasi, kemudian merumuskan masalah.

2) Persiapan kegiatan belajar mengajar (KBM) seperti : RPP, instrumen, dan media audiovisual berupa PPT dan video pembelajaran. Rencana pelaksanaan pembelajaran memuat pembelajaran yang akan dilakukan menggunakan metode discovery learning. Bahan-bahan yang dipersiapkan meliputi langkah-langkah metode discovery learning sebagai metode pembelajaran untuk siswa dan materi pelajaran yang akan diberikan untuk siswa. Instrumen yang dipersiapkan meliputi lembar penilaian dan lembar observasi, dan catatan lapangan. Media audiovisual dibagikan kepada siswa agar memahami materi yang disampaikan.

3) Penelitian siklus I ini dilaksanakan dalam 1 pertemuan, dilaksanakan pada hari senin , 02 November 2020 dengan alokasi 2 x 35 menit.

b. Pelaksanaan 
Tindakan Siklus I dilaksanakan dalam 1 kali pertemuan. Berikut ini merupakan deskripsi pelaksanaan tindakan pada masing-masing pertemuan.

Pelaksanaan penelitian ini berpedoman pada perencanaan yang telah dibuat. Adapun langkah-langkah dalam pembelajaran dengan menerapkan model pembelajaran menggunakan media audiovisual pada siklus I sebagai berikut:

Langkah pertama dalam pembelajaran adalah pendahuluan. Pembelajaran dimulai dengan guru mengucap salam kepada siswa dan menyapa wali murid melalui google meet serta mengajak peserta didik untuk menerapkan protokol kesehatan dalam kegiatan sehari-hari di masa pandemik covid sekarang ini. Kemudian memimpin doa bersama. Dilanjut dengan menyanyikan lagu Nasional. Di akhir kegiatan pendahuluan guru menyampaikan tujuan pembelajaran dan memberi semangat kepada siswa dan walimurid serta mengaitkan materi sebelumnya dengan materi yang akan dipelajari.

Langkah kedua adalah penyampaian materi. Pada langkah ini guru menyampaikan tentang pokok materi anggota keluarga inti, lagu sayang semuanya dan pancasila melalui media PPT. Namun sebelumnya siswa telah menonton terlebih dahulu video pembelajaran tentang anggota keluarga inti.

Langkah ketiga adalah tanya jawab dan diskusi bersama mengenai materi yang sedang dipelajari. Guru memberikan stimulus dan rangsangan berupa gambar / foto keluarga / pertanyaan kepada siswa kemudian siswa meresponnya.

Langkah keempat adalah penugasan. Pada langkah penugasan ini guru memberikan tugas pada LKPD yang sudah dibagikan. Guru mengulang kembali langkah-langkah yang harus dikerjakan oleh siswa. Tugasnya adalah siswa memperkenalkan anggota keluarganya dengan menunjukkan foto keluarganya kemudian direkam video.

Langkah kelima adalah penyampaian hasil. Siswa melakukan presentasi dengan memperkenalkan anggota keluarganya dihadapan teman-temannya berdasarkan petunjuk yang ada pada LKPD. Bagi siswa yang sudah berani presentasi diberi apresiasi oleh guru berupa penghargaan, pujian dan tepuk tangan dari guru dan siswa yang lain.

Langkah keenam adalah penutup. Guru bersama siswa membuat kesimpulan / rangkuman hasil belajar yang sudah dilaksanakan. Kemudian guru mengingatkan kembali untuk mematuhi protokol kesehatan serta tugas membuar video rekam perkenalan anggota keluarga yang harus dikirim ke guru. Dan untuk mengakhiri pembelajaran dengan membaca doa bersama.

c. Observasi

Hasil observasi yang dilakukan oleh observer selama jalannya kegiatan pembelajaran dan mengamati hasil evaluasi pada akhir kegiatan siklus pertama belum berhasil karena siswa yang tuntas hanya 10 siswa dari 22 siswa. Siswa yang sudah tuntas baru mencapai $45,5 \%$.

d. Refleksi

Pada pelaksanaan siklus I telah terjadi peningkatan keterampilan berbicara siswa yang dapat dilihat dari hasil data awal dengan rata-rata 67,54 meningkat menjadi 72,86. Dan untuk hasil ketuntasan siswa dari hasil tes awal siswa yang tuntas mencapai $27,3 \%$, sedangkan pada hasil evaluasi siklus I siswa yang tuntas mencapai $45,5 \%$. Hal ini menunjukkan ada peningkatan hasil belajar siswa sebesar 18,2\%. ini :

Untuk ketuntasan keterampilan berbicara siswa dapat dilihat pada tabel berikut 
Tabel 1. Persentase Ketuntasan Belajar Siklus I

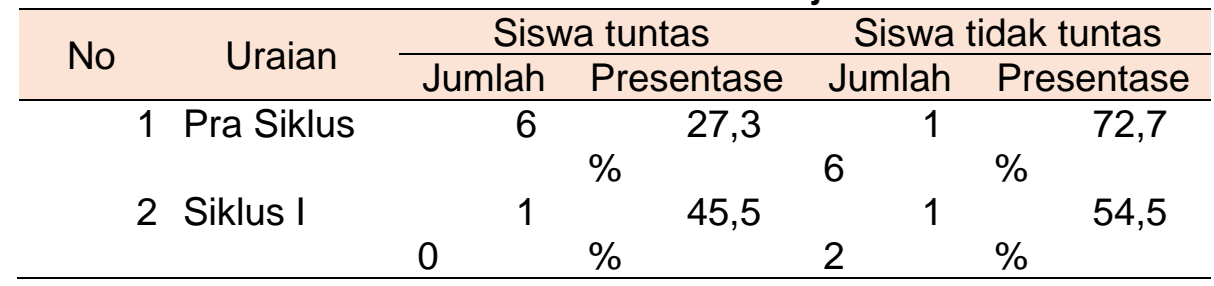

Pada tabel di atas dapat dijelaskan siswa yang belum tuntas belajar adalah sebagai berikut :

1. Pada kondisi awal atau Pra Siklus, siswa yang belum tuntas sebanyak 16 siswa dari 22 siswa atau $72,7 \%$.

2. Pada siklus I, siswa yang belum tuntas sebanyak 12 siswa dari 22 siswa atau $54,5 \%$.

Sedangkan siswa yang tuntas belajar adalah sebagai berikut :

1. Pada kondisi awal atau Pra Siklus, siswa yang tuntas sebanyak 6 siswa dari 22 siswa atau $27,3 \%$.

2. Pada siklus 1 , siswa yang tuntas sebanyak 10 siswa dari 22 siswa atau $45,5 \%$.

Lebih jelasnya lagi dapat dilihat pada gambar grafik Ketuntasan Minimal pembelajaran keterampilan berbicara di bawah ini :

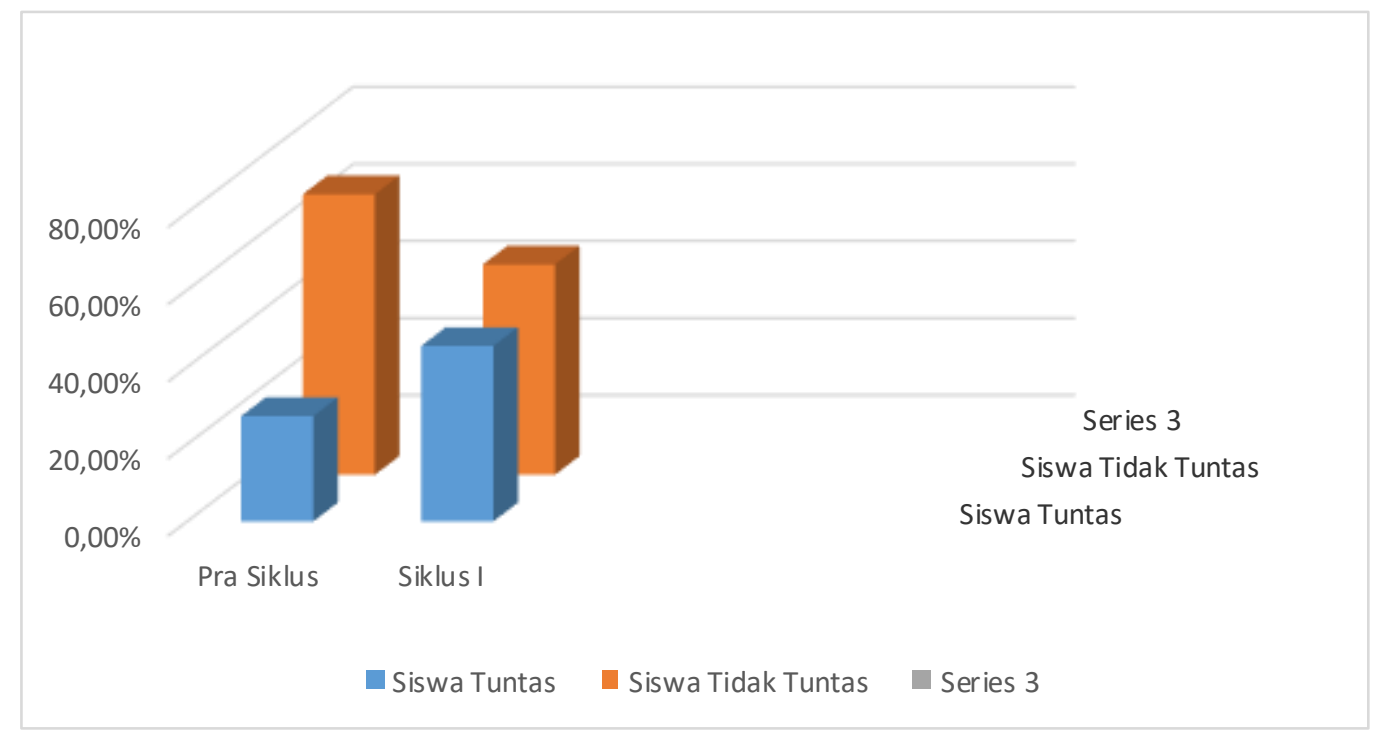

\section{Gambar 1 Grafik Kriteria Ketuntasan Minimal Pembelajaran Keterampilan Berbicara pada Siklus I}

Tindakan yang dilakukan pada siklus I dikatakan berhasil mencapai indikator ketercapaian siklus I yaitu 45,5\% dari keseluruhan siswa kelas I B yang memperoleh $\mathrm{KKM}>75$ dari keterampil berbicara. Namun, hasil yang diperoleh belum maksimal karena hanya $45,5 \%$ siswa yang mencapai $\mathrm{KKM}>75$. Oleh karena belum tercapainya indikator yang diharapkan maka perlu dilakukan siklus II sebagai langkah perbaikan dalam proses pembelajaran pada siklus I.

Pelaksanaan Tindakan Siklus 2

a. Perencanaan

Perencanaan tindakan dalam siklus I dapat diuraikan beberapa langkah yaitu sebagai berikut. 
1) Mengidentifikasi masalah melalui wawancara dengan guru kelas I B dan observasi, kemudian merumuskan masalah.

2) Persiapan kegiatan belajar mengajar (KBM) seperti : RPP, instrumen, dan media audiovisual berupa PPT dan video pembelajaran. Rencana pelaksanaan pembelajaran memuat pembelajaran yang akan dilakukan menggunakan metode discovery learning. Bahan-bahan yang dipersiapkan meliputi langkah-langkah metode discovery learning sebagai metode pembelajaran untuk siswa dan materi pelajaran yang akan diberikan untuk siswa. Instrumen yang dipersiapkan meliputi lembar penilaian dan lembar observasi, dan catatan lapangan. Media audiovisual dibagikan kepada siswa agar memahami materi yang disampaikan.

3) Penelitian siklus II ini dilaksanakan dalam 1 pertemuan, pertemuan pertama dilaksanakan pada hari senin , 09 November 2020 dengan alokasi 2 x 35 menit.

b. Pelaksanaan

Tindakan Siklus 2 dilaksanakan dalam 1 kali pertemuan. Berikut ini merupakan deskripsi pelaksanaan tindakan. Pelaksanaan penelitian ini berpedoman pada perencanaan yang telah dibuat. Adapun langkah-langkah dalam pembelajaran dengan menerapkan model pembelajaran menggunakan media audiovisual pada siklus 2 pertemuan 1 sebagai berikut:

Langkah pertama dalam pembelajaran adalah pendahuluan. Pembelajaran dimulai dengan guru mengucap salam kepada siswa dan menyapa wali murid melalui zoom meeting serta mengajak peserta didik untuk menerapkan protokol kesehatan dalam kegiatan sehari-hari di masa pandemik covid sekarang ini. Kemudian memimpin doa bersama. Dilanjut dengan menyanyikan lagu Nasional. Di akhir kegiatan pendahuluan guru menyampaikan tujuan pembelajaran dan memberi semangat kepada siswa dan walimurid serta mengaitkan materi sebelumnya dengan materi yang akan dipelajari.

Langkah kedua adalah penyampaian materi. Pada langkah ini guru menyampaikan tentang pokok materi anggota keluarga inti, lagu sayang semuanya dan pancasila melalui media PPT. Namun sebelumnya siswa telah menonton terlebih dahulu video pembelajaran tentang anggota keluarga inti.

Langkah ketiga adalah tanya jawab dan diskusi bersama mengenai materi yang sedang dipelajari. Guru memberikan stimulus dan rangsangan berupa gambar / foto keluarga / pertanyaan kepada siswa kemudian siswa meresponnya.

Langkah keempat adalah penugasan. Pada langkah penugasan ini guru memberikan tugas pada LKPD yang sudah dibagikan. Guru mengulang kembali langkah-langkah yang harus dikerjakan oleh siswa. Tugasnya adalah siswa memperkenalkan anggota keluarganya dengan menunjukkan foto keluarganya kemudian direkam video.

Langkah kelima adalah penyampaian hasil. Siswa melakukan presentasi dengan memperkenalkan anggota keluarga besarnya dihadapan teman-temannya berdasarkan petunjuk yang ada pada LKPD. Bagi siswa yang sudah berani presentasi diberi apresiasi oleh guru berupa penghargaan, pujian dan tepuk tangan dari guru dan siswa yang lain.

Langkah keenam adalah penutup. Guru bersama siswa membuat kesimpulan / rangkuman hasil belajar yang sudah dilaksanakan. Kemudian guru mengingatkan kembali untuk mematuhi protokol kesehatan serta tugas membuar video rekam perkenalan anggota keluarga yang harus dikirim ke guru. Dan untuk mengakhiri pembelajaran dengan membaca doa bersama.

c. Observasi

Hasil observasi yang dilakukan oleh observer selama jalannya kegiatan pembelajaran dan mengamati hasil evaluasi pada akhir kegiatan siklus kedua bisa dikatakan sudah berhasil karean siswa yang tuntas sebanyak 17 siswa dari 22 siswa. Dengan kata lain siswa yang tuntas sudah mencapai $77,3 \%$. Namun, meskipun 
ketuntasan sudah mencapai $75 \%$ masih diperlukan perbaikan karena masih ada 5 siswa yang nilainya di bawah KKM.

d. Refleksi

Hasil yang diperoleh dari tindakan siklus II melalui pengamatan dan penilaian hasil keterampilan bercerita kemudian dianalisis. Berdasarkan hasil observasi dan tes unjuk kerja keterampilan berbicara siswa pada siklus II, telah terjadi peningkatan pada keterampilan berbicara siswa yang dapat dilihat dari hasil rata-rata keterampilan berbicara siswa pada siklus II adalah 75,86 dengan nilai ketuntasan siswa yang tuntas ada 17 anak dari 22 siswa atau 77,3\%. Pada siklus II tidak terjadi hambatan yang berarti dan semua pembelajaran dapat berjalan dengan lancar

Berdasarkan hasil evaluasi siklus II tersebut, dapat dilihat presentase ketuntasan belajar siklus II sebagai berikut :

Tabel 2. Persentase Ketuntasan Belajar Siklus II

\begin{tabular}{llrrrr}
\hline \multirow{2}{*}{ No } & \multirow{2}{*}{ Uraian } & \multicolumn{2}{c}{ Siswa tuntas } & \multicolumn{2}{c}{ Siswa tidak tuntas } \\
& & Jumlah & Presentase & Jumlah & Presentase \\
\hline 1 & Pra Siklus & 6 & $27,3 \%$ & 16 & $72,7 \%$ \\
2 & Siklus I & 10 & $45,5 \%$ & 12 & $54,5 \%$ \\
3 & Siklus II & 17 & $77,3 \%$ & 5 & $22,7 \%$ \\
\hline
\end{tabular}

Pada tabel di atas dapat dijelaskan siswa yang belum tuntas belajar adalah sebagai berikut :

1. Pada kondisi awal atau Pra Siklus, siswa yang belum tuntas sebanyak 16 siswa dari 22 siswa atau $72,7 \%$.

2. Pada siklus I, siswa yang belum tuntas sebanyak 12 siswa dari 22 siswa atau $54,5 \%$.

3. Pada siklus II, siswa yang belum tuntas sebanyak 5 siswa dari 22 siswa atau $22,7 \%$

Sedangkan siswa yang tuntas belajar adalah sebagai berikut :

1. Pada kondisi awal atau Pra Siklus, siswa yang tuntas sebanyak 6 siswa dari 22 siswa atau $27,3 \%$.

2. Pada siklus 1, siswa yang tuntas sebanyak 10 siswa dari 22 siswa atau 45,5\%.

3. Pada Siklus II, siswa yang tuntas sebanyak 17 siswa dari 22 siswa atau $77,3 \%$.

Lebih jelasnya lagi dapat dilihat pada gambar grafik Ketuntasan Minimal pembelajaran keterampilan berbicara di bawah ini :

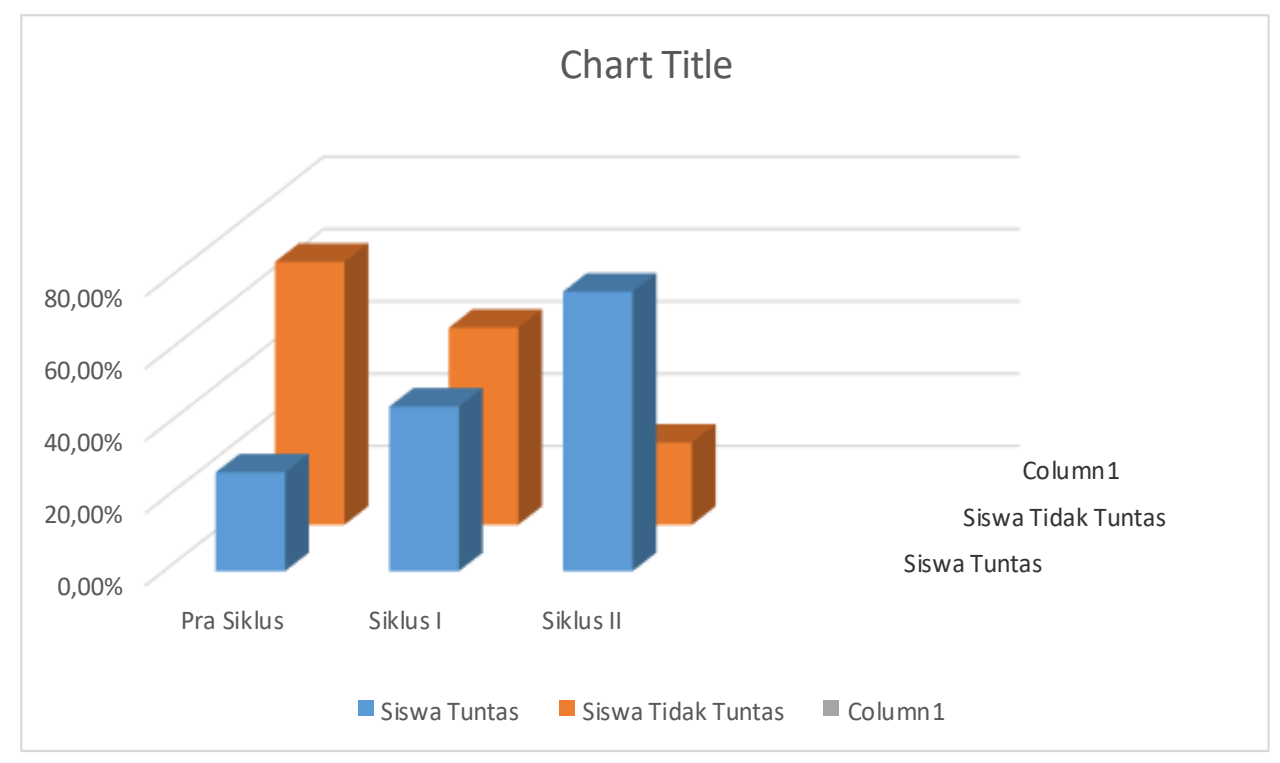




\section{Gambar 2 Grafik Kriteria Ketuntasan Minimal Pembelajaran Keterampilan Berbicara pada Siklus II}

Berdasarkan tabel pembelajaran pada Siklus II menunjukkan peningkatan ratarata kelas dan peningkatan jumlah siswa yang memperoleh nilai $\geq 75$ sehingga pembelajaran pada siklus II sudah berhasil. Dan masih ada 5 siswa yang masih belum tuntas KKM.

\section{SIMPULAN}

Penggunaan media audiovisual dapat meningkatkan hasil belajar siswa pada materi Bahasa Indonesia kelas I B SD Negeri Suro Kecamatan Kalibagor, hal ini dibuktikan dari hasil belajar pada kondisi awal sesuai dengan latar belakang penelitian, siswa yang belum tuntas sebanyak 16 siswa dari 22 siswa atau 72,7 \% untuk siswa yang tuntas sebanyak 6 siswa atau 27,3\%. Pada siklus I siswa yang belum tuntas berkurang menjadi 10 siswa dari 22 siswa atau 45,5\%, sedangkan siswa yang tuntas sebanyak 12 siswa dari 22 siswa atau $54,5 \%$. Pada siklus II, siswa yang belum tuntas sebanyak 5 siswa dari 22 siswa atau 22,7\%, sedangkan siswa yang tuntas sebanyak 17 siswa dari 22 siswa atau 77,3\%. Ini artinya hasil belajar siswa meningkat dari siklus I ke siklus II.

Implikasi serta rekomendasi,Hendaknya guru mengembangkan pembelajaran menggunakan media audiovisual pada pelajaran yang lain.

\section{DAFTAR PUSTAKA}

Arif Sadiman., dkk. 2003. Media Pendidikan (Pengertian Pengembangan dan Pemafaatannya). Jakarta: CV Rajawali.

Arsyhar, Rayandra. 2012. Media Pembelajaran. Edisi 1. Jakarta:Referensi Jakarta Asyhar, Rayandra 2012. Kreatif Mengembangkan Media Pembelajaran. Jakarta: Refrensi Jakrata.

Hamalik, Oemar. 2001. Proses Belajar Mengajar. Jakarta: Bumi Aksara. Hernawan, Asep Heri, dkk. 2009. Pengembangan Kurikulum dan Pembelajaran. Jakarta: Universitas Terbuka.

Mamat, S.B. dkk, 2007. Pedoman Pelaksanaan Pembelajaran Tematik. Jakarta: Dirjen Kelembagaan Agama Islam.

Sudjana, Nana. 2008. Penilaian Hasil Proses Belajar Mangajar. Bandung: PT Remaja Rosdakarya.

Sugiyono. (2011). Metode Penelitian Kuantitaif, Kualitatif, dan R\&D. Bandung: Alfabeta CV

Tadkiroatun Musfiroh. (2005). Bercerita untuk Anak Usia Dini. Jakarta: Dirjen Dikti.

Yudhi Munadi. (2013) Media Pembelajaran. Jakarta: GP Press Goup 